\section{BRAZIULIAN JOURNAL \\ OF MEDICAL AND BIOLOGICAL RESF.ARCH}

www.bjournal.com.br
ISSN 0100-879X

Volume 42 (12) 1119-1247 December 2009

BIOMEDICAL SCIENCES

AND

CLINICAL INVESTIGATION

Braz J Med Biol Res, December 2009, Volume 42(12) 1191-1195

Oral rapamycin attenuates atherosclerosis without affecting the arterial responsiveness of resistance vessels in apolipoprotein E-deficient mice

A.L.N. Gadioli, B.V. Nogueira, R.M.P. Arruda, R.B. Pereira, S.S. Meyrelles, J.A. Arruda and E.C. Vasquez

The Brazilian Journal of Medical and Biological Research is partially financed by
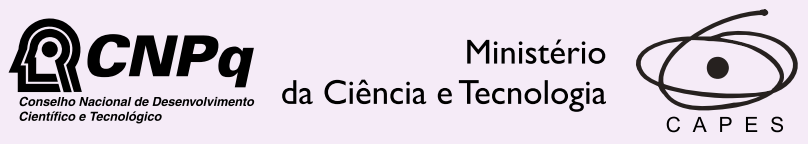

Ministério da Educação

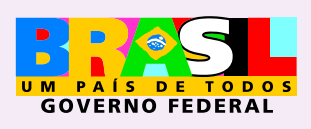

Institutional Sponsors 


\title{
Oral rapamycin attenuates atherosclerosis without affecting the arterial responsiveness of resistance vessels in apolipoprotein E-deficient mice
}

\author{
A.L.N. Gadioli ${ }^{1}$, B.V. Nogueira1 ${ }^{1}$, R.M.P. Arruda1 ${ }^{1}$, R.B. Pereira1 ${ }^{1}$, S.S. Meyrelles ${ }^{1}$, \\ J.A. Arruda ${ }^{1}$ and E.C. Vasquez $z^{1,2}$ \\ 1'Laboratório de Transgenes e Controle Cardiovascular, Programa de Pós-Graduação em Ciências Fisiológicas, \\ Centro de Ciências da Saúde, Universidade Federal do Espírito Santo, Vitória, ES, Brasil \\ ${ }^{2}$ Centro de Pesquisa, Escola Superior de Ciências, Santa Casa de Misericórdia de Vitória, Vitória, ES, Brasil
}

\begin{abstract}
The objective of the present study was to assess the effects of the immunosuppressant rapamycin (Rapamune ${ }^{\circledR}$, Sirolimus) on both resistance vessel responsiveness and atherosclerosis in apolipoprotein E-deficient 8-week-old male mice fed a normal rodent diet. Norepinephrine (NE)-induced vasoconstriction, acetylcholine (ACh)- and sodium nitroprusside (SNP)-induced vasorelaxation of isolated mesenteric bed, and atherosclerotic lesions were evaluated. After 12 weeks of orally administered rapamycin $\left(5 \mathrm{mg} \cdot \mathrm{kg}^{-1} \cdot \mathrm{day}^{-1}, \mathrm{~N}=9\right)$ and compared with untreated (control, $\mathrm{N}=9$ ) animals, rapamycin treatment did not modify either NE-induced vasoconstriction (maximal response: $114 \pm 4$ vs $124 \pm 10 \mathrm{mmHg}$, respectively) or ACh- (maximal response: $51 \pm 8$ vs $53 \pm 5 \%$, respectively) and SNP-induced vasorelaxation (maximal response: $73 \pm 6$ vs $74 \pm 6 \%$, respectively) of the isolated vascular mesenteric bed. Despite increased total cholesterol in treated mice (982 $\pm 59 \mathrm{vs} 722 \pm 49 \mathrm{mg} / \mathrm{dL}, \mathrm{P}<0.01)$, lipid deposition on the aorta wall vessel was significantly less in rapamycin-treated animals $\left(37 \pm 12\right.$ vs $\left.68 \pm 8 \mu \mathrm{m}^{2} \times 10^{3}\right)$. These results indicate that orally administered rapamycin is effective in attenuating the progression of atherosclerotic plaque without affecting the responsiveness of resistance vessels, supporting the idea that this immunosuppressant agent might be of potential benefit against atherosclerosis in patients undergoing therapy.
\end{abstract}

Key words: Rapamycin; Sirolimus; Atherosclerosis; Vascular responsiveness; Apolipoprotein E; Mice

\section{Introduction}

Rapamycin (Rapamune ${ }^{\circledR}$, Sirolimus) is an antifungal agent with antiproliferative and immunosuppressant properties used to prevent rejection of transplanted organs (1). The mechanism of action of rapamycin is a blockade of the response of $T$ and $B$ cells to cytokines, thereby preventing cell cycle progression in $\mathrm{G} 1$ and cell proliferation (2). The primary vascular effects of this drug include the inhibition of smooth muscle and endothelial cell proliferation (3).

Abnormal vascular smooth muscle cell proliferation and migration contribute to the development of restenosis after percutaneous transluminal coronary angioplasty (4). Rapamycin has also been shown to be effective in decreasing coronary artery restenosis in humans when eluted from implanted stents and, consequently, this treatment is commonly used in percutaneous coronary interventions $(5,6)$. However, some studies, which focused on the understanding of the effects of this drug on vascular function, have shown that, in contrast to bare metal stents, rapamycin-eluting stents impair endothelial function, as indicated by an acetylcholine-induced coronary vasoconstrictive response in the proximal and distal stent segments $(7,8)$.

Oral administration of rapamycin has been proposed as an alternative to drug-eluting stents, especially when multiple stenting is recommended (9), thus raising the necessity to investigate the potential effects of this agent on the vessels. Focusing on this issue, Milliard et al.

Correspondence: E.C. Vasquez, Centro de Pesquisa, Escola Superior de Ciências, Santa Casa de Misericórdia de Vitória, EMESCAM, Av. Nossa Senhora da Penha, 2190, 29045-420 Vitoria, ES, Brasil. Fax: +55-27-3334-3558.

E-mail: elisardo.vasquez@emescam.br

Received July 3, 2009. Accepted October 8, 2009. Available online November 6, 2009. Published December 4, 2009. 
(10) showed that systemic treatment with rapamycin (2 $\mathrm{mg} / \mathrm{kg}$ ) for 2 weeks attenuated the vasoconstriction and potentiated the endothelium-dependent vasorelaxation of aortic rings in Sprague-Dawley rats. In contrast, Neto et al. (11) showed that orally administered rapamycin at the same dose and for the same treatment duration did not affect the vascular tone of Wistar rats. Alternatively, studies on mice have been limited to the evaluation of the effects of rapamycin on the progression of atherosclerotic plaque in apolipoprotein $\mathrm{E}$ (apoE) knockout mice fed a high-cholesterol diet $(12,13)$. However, we should consider the physiological importance of studying the effect of this drug on the responsiveness of resistance vessels and on atherosclerosis in this murine model of spontaneous atherosclerosis without the perturbation caused by a supplemented high-fat diet. Therefore, the present study was designed to assess the effects of orally administered rapamycin on the vasoconstriction and vasodilation of the vascular mesenteric bed and on the atherosclerotic plaque of apoE knockout mice fed a normal rodent diet.

\section{Material and Methods}

\section{Animals and treatment}

Experiments were conducted on young (eight weeks of age; averaging $23 \mathrm{~g}$ ) male apoE knockout mice obtained from the animal facilities of the Health Sciences Center, Federal University of Espírito Santo. The animals were fed a normal chow rodent diet and water ad libitum. All animal procedures were approved in advance by the institutional Ethics Committee for Use of Animals (CEUA-EMESCAM, Protocol \#022/2007) and were conducted in accordance with the international guidelines for care and use of laboratory animals.

Rapamycin (Rapamune ${ }^{\circledR}$, Wyeth-Ayerst, USA) was admixed with the diet of the treated group to deliver an oral dose of $5 \mathrm{mg} / \mathrm{kg}$ per day for 12 weeks.

\section{Preparation of the mesenteric arteriolar bed}

The superior mesenteric artery was cannulated using a catheter $\left(0.040 \mathrm{~mm}\right.$ OD x $0.025 \mathrm{ID}$; Micro-Renathane ${ }^{\circledR}$; Braintree Science) under thiopental $(40 \mathrm{mg} / \mathrm{kg}$, ip) anesthesia. The mesenteric arteriolar bed was then placed in a vessel containing water at $37^{\circ} \mathrm{C}$ and perfused at a constant rate $(2 \mathrm{~mL} / \mathrm{min})$ with oxygenated $\left(95 \% \mathrm{O}_{2}-5 \% \mathrm{CO}_{2}\right.$ mixture) physiological salt solution using a roller pump (Harvard Apparatus, USA). The composition of the solution was as follows: $130 \mathrm{mM} \mathrm{NaCl}, 4.7 \mathrm{mM} \mathrm{KCl}, 1.6 \mathrm{mM}$ $\mathrm{CaCl}_{2} .2 \mathrm{H}_{2} \mathrm{O}, 1.8 \mathrm{mM} \mathrm{KH}_{2} \mathrm{PO}_{4}, 1.17 \mathrm{mM} \mathrm{MgSO} 4.7 \mathrm{H}_{2} \mathrm{O}$, $14.9 \mathrm{mM} \mathrm{NaHCO}_{3}, 0.026 \mathrm{mM}$ EDTA, and $11.1 \mathrm{mM}$ glucose. Perfusion pressure was monitored via a T-tube inserted between the pump and the inflow cannula and connected to a pressure transducer (Cobe Laboratories, USA) and a data acquisition system (BioPac Systems, USA). First, we studied the dose-dependent contractions to $0.1 \mu \mathrm{M}$ to
0.2 M norepinephrine (NE; Sigma Chemical Co., USA). To study endothelial function, vasodilator responses to 1 $\mathrm{nM}$ to $10 \mathrm{mM}$ acetylcholine (ACh; Sigma) and $1 \mathrm{nM}$ to 10 mM sodium nitroprusside (SNP; Sigma) were calculated as percent reduction in the precontractions induced by $5 \mu \mathrm{M} \mathrm{NE}$ (a concentration that induces 60 to $80 \%$ of the maximal effect).

\section{Measurement of plasma cholesterol levels}

A blood sample was taken from the carotid artery and total plasma cholesterol was measured using a commercial colorimetric kit (Bioclin, Brazil).

\section{Histological vessel processing and morphometry}

Immediately after the isolation and removal of the vascular mesenteric bed, the animals were perfused via the left ventricle with $0.1 \mathrm{M}$ phosphate-buffered saline, $\mathrm{pH} 7.4$, followed by a fixative solution containing $4 \%$ paraformaldehyde. After overnight incubation in the fixative solution, the heart and the ascending aorta were embedded in $24 \%$ $(\mathrm{w} / \mathrm{v})$ gelatin solution, and $10-\mu \mathrm{m}$ serial sections were cut from the level of the aortic valve leaflets up to the curve of the aorta arch with a $-20^{\circ} \mathrm{C}$ cryostat (Jung CM 1800, Leica, Germany). Aorta cross-sections were mounted on gelatincoated slides and stained with either oil-red-O (Sigma) for the detection of neutral lipids or with hematoxylin-eosin (Sigma) for morphological analysis performed by an independent investigator.

Images were captured with a color video camera (VKC150, Hitachi, Japan) connected to a microscope (Olympus AX70, USA) and analyzed with a specific image program (2100 Leica EWS, Germany) by an examiner blinded to the treatment group. The lipid deposition area was quantified by selecting and averaging the five most highly stained cross-sections of the aorta of each animal.

\section{Statistical analysis}

Data are reported as means \pm SEM. Statistical analysis was performed by two-way ANOVA followed by the Fisher test for multiple comparisons. Comparisons of mean values between two groups were performed by the unpaired Student $t$-test whenever needed. A two-tailed $\mathrm{P} \leq 0.05$ value was accepted as statistically significant.

\section{Results}

ApoE-deficient mice treated with orally administered rapamycin gained similar amounts of body weight and were as active as control mice.

The data in Figure 1 provide the dose-effect curve for NE, ACh and SNP in long-term rapamycin-treated and control apoE-deficient mice. The basal perfusion pressure of the isolated mesenteric bed was similar in both groups. The vascular constriction response to NE was also similar in treated and control animals, as indicated by the maximal 

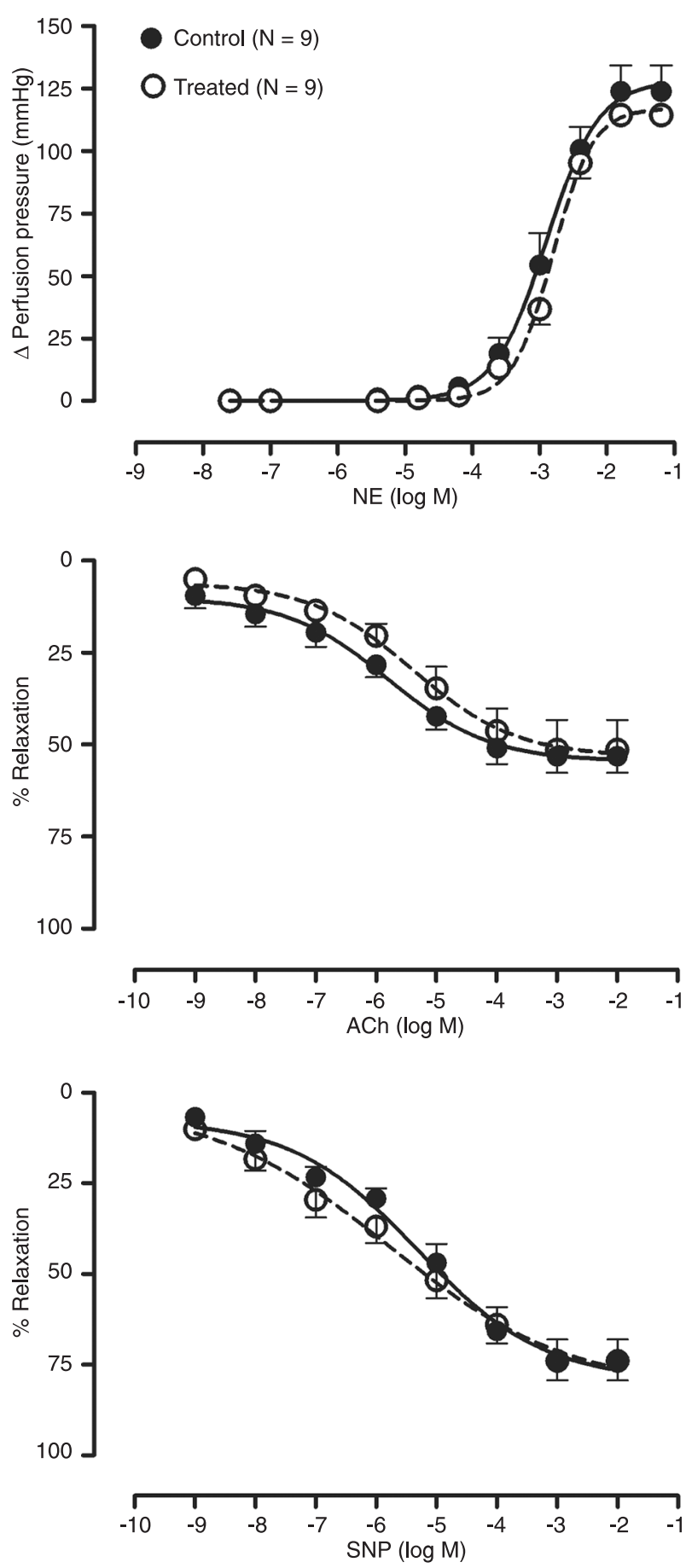

Figure 1. Concentration-dependent contraction of isolated mesenteric arteries of apolipoprotein E-deficient mice in response to norepinephrine (NE) and endothelium-dependent relaxation in response to acetylcholine (ACh) or endotheliumindependent relaxation to sodium nitroprusside (SNP). The mice received $5 \mathrm{mg} / \mathrm{kg}$ rapamycin daily for 12 weeks (treated) and were compared with untreated (control) animals. Each point indicates means \pm SEM response (114 \pm 4 vs $124 \pm 10 \mathrm{mmHg}$, respectively) and the $\log \mathrm{ED}_{50}(-2.80 \pm 0.04$ vs $-2.90 \pm 0.09 \mathrm{M}$, respectively). The endothelium-dependent relaxation in response to ACh was similar in treated and control mice in terms of maximal response (51 \pm 8 vs $53 \pm 5 \%$, respectively) and $\log \mathrm{ED}_{50}(-5.40 \pm 0.40 \mathrm{vs}-5.80 \pm 0.31 \mathrm{M}$, respectively). The endothelium-independent vascular smooth muscle relaxation to SNP was also unchanged by rapamycin treatment compared to control mice: maximal response (73 \pm 6 vs $74 \pm 6 \%$, respectively) and $\log \mathrm{ED}_{50}(-5.78 \pm 0.51$ vs -5.31 $\pm 0.31 \mathrm{M}$, respectively).

Plasma cholesterol levels were significantly higher in rapamycin-treated than in control animals (982 \pm 59 vs 722 $\pm 49 \mathrm{mg} / \mathrm{dL}, \mathrm{P}<0.01)$.

Figure 2 shows typical microphotographs of aortic root sections. Rapamycin-treated mice displayed a marked reduction in the area of oil-red-O-stained atherosclerotic plaque compared with control mice. The average values of lipid deposition in the vessel sections were significantly less in treated than in control animals ( $37 \pm 12$ vs $68 \pm 8$ $\mu \mathrm{m}^{2} \times 10^{3}$; bar graph in Figure 2).

\section{Discussion}

In the present study, we show that long-term orally administered rapamycin attenuates the development of vascular atherosclerotic plaque, but does not affect either the vasoconstriction induced by NE or the endotheliumdependent vasorelaxation induced by ACh in apoE-deficient mice fed a normal diet.

The development of drug-eluting stents, and in particular rapamycin-coated stents, was a milestone in the treatment of obstructive coronary atherosclerosis disease. These new devices are associated with a dramatic and sustained reduction of the restenosis process, as can be observed from several clinical trials $(6,14,15)$. In another field of application, oral administration of rapamycin has been proposed as an alternative to drug-eluting stents for preventing in-stent restenosis after percutaneous coronary intervention $(9,16,17)$. However, it is important to establish other benefits of rapamycin, including the regression of atherosclerosis that affects mainly large conductance vessels and the control of the circulation that is mainly exerted by resistance vessels, as well as to address concerns regarding toxicity and late adverse side effects (14).

Regarding the effects of systemic treatment with rapamycin on arterial vessel tone and endothelial function, studies have been restricted to the rat and have shown conflicting results $(10,11)$. One of these two studies showed that rapamycin significantly attenuated the vasoconstriction and potentiated the endothelium-dependent vasorelaxation of aortic rings (10) and the other showed that orally administered rapamycin at the same dose and for the same treatment duration did not affect the vascular tone (11). Because this experimental animal does not develop athero- 


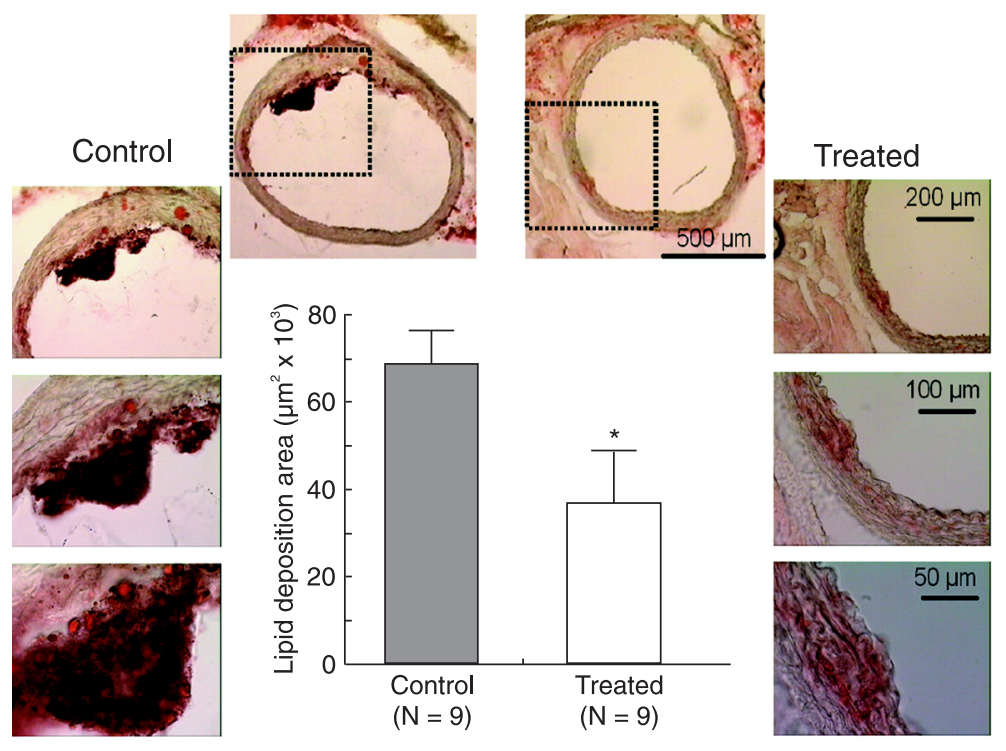

Figure 2. Effect of oral rapamycin (treated) for 12 weeks on atherosclerotic plaque formation in apolipoprotein E-deficient mice compared to untreated (control) mice. Typical photomicrographs, at low (40X) and high (100 to 400X) magnification, are from aortic root sections stained with oil-red-O to visualize lipid-rich lesions and counterstained with hematoxylin-eosin. Histogram shows the average lipid deposition area in aortic root sections. Data are reported as means \pm SEM. ${ }^{*} \mathrm{P}<0.05$ vs control group (Student $t$-test).

sclerosis, the effect of systemic administration of rapamycin on atherosclerosis could not be considered.

Following the advancement of molecular biology and the development of gene knockout technology, the apoEdeficient mouse has become a valuable tool in elucidating mechanisms and assessing therapeutic strategies against atherosclerosis and other cardiovascular diseases. In the present study, we demonstrate that orally administered rapamycin ( $5 \mathrm{mg} / \mathrm{kg}$, for 12 weeks) does not modify the vascular constriction in response to NE or the vascular relaxation in response to $\mathrm{ACh}$ (endothelium-dependent action) or SNP (endothelium-independent action) of isolated arterial mesenteric beds in apoE-deficient mice fed a normal rodent diet. Although the murine model of atherosclerosis is not fully comparable to the human situation, the present result is important because it shows that long-term administration of high doses of rapamycin maintains the normal function of resistance vessels, which is an important consideration favoring the therapeutic use of this immunosuppressant agent in transplant patients. Further experiments are necessary to determine if rapamycin also preserves the normal responsiveness of conductance vessels (aorta) in the murine model of spontaneous atherosclerosis.

In our study, apoE-deficient mice showed high total serum cholesterol levels, in agreement with results from the investigators who introduced this murine model $(18,19)$ and with previous studies from our group $(20,21)$. We observed that orally administered rapamycin increased total cholesterol levels in apoE-deficient mice fed a normal rodent diet compared with untreated animals. Interest- ingly, when hypercholesterolemia in apoE-deficient mice is severely aggravated by a high-fat supplemented diet, the hypercholesterolemic effect of rapamycin has been observed by some (22) but not by others even with the use of a high-dose, long-term rapamycin treatment $(13,23,24)$. Importantly, our result obtained in this murine model of spontaneous atherosclerosis agrees with the general clinical concept that the increase in cholesterol is a side effect of rapamycin treatment (25).

There is a consensus that rapamycin significantly reduces the aortic atherosclerotic plaque in apoE-deficient mice fed a fat-rich diet $(12,13,22,23,26)$. In the present study, we also observed similar anti-atherosclerotic effects of rapamycin administered to the apoE-deficient mice fed a normal rodent diet. On the basis of other studies, there are several possible mechanisms by which rapamycin, in addition to being a potent immunosuppressant and antiproliferative agent, could decrease vascular atherosclerotic lesions. One of the first studies showed that orally administered rapamycin significantly inhibited aortic smooth muscle cell migration (4). Oral rapamycin also effectively slows the progression of atherosclerosis by attenuating monocyte chemotaxis (13). Ma et al. (27) showed that inhibition of lipid uptake together with increasing cholesterol efflux and the inhibition of inflammatory cytokines are all important aspects of the anti-atherosclerotic effects of rapamycin on smooth muscle cells. In addition, overexpression of eNOS may also contribute to the changes observed in the aorta of apoE-deficient mice induced by rapamycin (24).

The data presented here indicate that orally adminis- 
tered rapamycin is effective in attenuating the progression of atherosclerotic plaque without affecting the responsiveness of resistance vessels, suggesting that this immunosuppressant agent might be of benefit regarding atherosclerosis in patients undergoing therapy, independent of changes in circulating lipids.

\section{References}

1. Sehgal SN. Sirolimus: its discovery, biological properties, and mechanism of action. Transplant Proc 2003; 35: 7S-14S.

2. Dumont FJ, Su Q. Mechanism of action of the immunosuppressant rapamycin. Life Sci 1996; 58: 373-395.

3. Mohacsi PJ, Tuller D, Hulliger B, Wijngaard PL. Different inhibitory effects of immunosuppressive drugs on human and rat aortic smooth muscle and endothelial cell proliferation stimulated by platelet-derived growth factor or endothelial cell growth factor. J Heart Lung Transplant 1997; 16: 484-492.

4. Poon M, Marx SO, Gallo R, Badimon JJ, Taubman MB, Marks AR. Rapamycin inhibits vascular smooth muscle cell migration. J Clin Invest 1996; 98: 2277-2283.

5. Serruys PW, Regar E, Carter AJ. Rapamycin eluting stent: the onset of a new era in interventional cardiology. Heart 2002; 87: 305-307.

6. Moses JW, Leon MB, Popma JJ, Fitzgerald PJ, Holmes DR, O'Shaughnessy C, et al. Sirolimus-eluting stents versus standard stents in patients with stenosis in a native coronary artery. N Engl J Med 2003; 349: 1315-1323.

7. Fuke S, Maekawa K, Kawamoto K, Saito H, Sato T, Hioka T, et al. Impaired endothelial vasomotor function after sirolimuseluting stent implantation. Circ J 2007; 71: 220-225.

8. Hamilos MI, Ostojic M, Beleslin B, Sagic D, Mangovski L, Stojkovic S, et al. Differential effects of drug-eluting stents on local endothelium-dependent coronary vasomotion. J Am Coll Cardiol 2008; 51: 2123-2129.

9. Brito FS Jr, Rosa WC, Arruda JA, Tedesco H, Pestana JO, Lima VC. Efficacy and safety of oral sirolimus to inhibit in-stent intimal hyperplasia. Catheter Cardiovasc Interv 2005; 64: 413-418.

10. Milliard S, Silva A, Blaise G, Chen H, Xu D, Qi S, et al. Rapamycin's effect on vasomotion in the rat. Transplant Proc 1998; 30: 1036-1038.

11. Neto MM, Di Marco GS, Casarini DE, Lima VC, Campos AH. Orally administered rapamycin does not modify rat aortic vascular tone. J Cardiovasc Pharmacol 2007; 49: 96-99.

12. Waksman R, Pakala R, Burnett MS, Gulick CP, Leborgne L, Fournadjiev J, et al. Oral rapamycin inhibits growth of atherosclerotic plaque in apoE knock-out mice. Cardiovasc Radiat Med 2003; 4: 34-38.

13. Pakala R, Stabile E, Jang GJ, Clavijo L, Waksman R. Rapamycin attenuates atherosclerotic plaque progression in apolipoprotein $E$ knockout mice: inhibitory effect on monocyte chemotaxis. J Cardiovasc Pharmacol 2005; 46: 481-486.

14. Ruygrok PN, Muller DW, Serruys PW. Rapamycin in cardiovascular medicine. Intern Med J 2003; 33: 103-109.

15. Mauri L, Silbaugh TS, Wolf RE, Zelevinsky K, Lovett A, Zhou $Z$, et al. Long-term clinical outcomes after drug-eluting and bare-metal stenting in Massachusetts. Circulation 2008; 118: 1817-1827.

\section{Acknowledgments}

We thank Wyeth-Ayerst Laboratories (USA) for providing rapamycin. Research supported by CNPq (Ref. Universal 2007 Grant), Central Laboratory of the State Department of Health (LACEN-SESA), and FAPES (Ref. PPSUS and PRONEX).

16. Arruda JA, Costa MA, Brito FS Jr, Tedesco H, Barbosa AH, Ribeiro EP, et al. Effect of systemic immunosuppression on coronary in-stent intimal hyperplasia in renal transplant patients. Am J Cardiol 2003; 91: 1363-1365.

17. Rodriguez AE, Rodriguez AM, Vigo CF, Fernandez PC, Llaurado $\mathrm{C}$, Vetcher $\mathrm{D}$, et al. Role of oral rapamycin to prevent restenosis in patients with de novo lesions undergoing coronary stenting: results of the Argentina single centre study (ORAR trial). Heart 2005; 91: 1433-1437.

18. Piedrahita JA, Zhang SH, Hagaman JR, Oliver PM, Maeda N. Generation of mice carrying a mutant apolipoprotein $\mathrm{E}$ gene inactivated by gene targeting in embryonic stem cells. Proc Natl Acad Sci U S A 1992; 89: 4471-4475.

19. Plump AS, Smith JD, Hayek T, Aalto-Setala K, Walsh A, Verstuyft JG, et al. Severe hypercholesterolemia and atherosclerosis in apolipoprotein E-deficient mice created by homologous recombination in ES cells. Cell 1992; 71: 343-353.

20. Arruda RM, Peotta VA, Meyrelles SS, Vasquez EC. Evaluation of vascular function in apolipoprotein $E$ knockout mice with angiotensin-dependent renovascular hypertension. Hypertension 2005; 46: 932-936.

21. Nogueira BV, Peotta VA, Meyrelles SS, Vasquez EC. Evaluation of aortic remodeling in apolipoprotein E-deficient mice and renovascular hypertensive mice. Arch Med Res 2007; 38: 816-821.

22. Elloso MM, Azrolan N, Sehgal SN, Hsu PL, Phiel KL, Kopec $\mathrm{CA}$, et al. Protective effect of the immunosuppressant sirolimus against aortic atherosclerosis in apo E-deficient mice. Am J Transplant 2003; 3: 562-569.

23. Castro C, Campistol JM, Sancho D, Sanchez-Madrid F, Casals E, Andres V. Rapamycin attenuates atherosclerosis induced by dietary cholesterol in apolipoprotein-deficient mice through a p27 Kip1-independent pathway. Atherosclerosis 2004; 172: 31-38.

24. Naoum JJ, Woodside KJ, Zhang S, Rychahou PG, Hunter GC. Effects of rapamycin on the arterial inflammatory response in atherosclerotic plaques in Apo-E knockout mice. Transplant Proc 2005; 37: 1880-1884.

25. Kelly PA, Gruber SA, Behbod F, Kahan BD. Sirolimus, a new, potent immunosuppressive agent. Pharmacotherapy 1997; 17: 1148-1156.

26. Basso MD, Nambi P, Adelman SJ. Effect of sirolimus on the cholesterol content of aortic arch in ApoE knockout mice. Transplant Proc 2003; 35: 3136-3138.

27. Ma KL, Ruan XZ, Powis SH, Moorhead JF, Varghese Z. Antiatherosclerotic effects of sirolimus on human vascular smooth muscle cells. Am J Physiol Heart Circ Physiol 2007; 292: $\mathrm{H} 2721-\mathrm{H} 2728$. 